\title{
ASSESSMENT OF FACTORS AFFECTING THE FOREIGN INVESTMENT ATTRACTION IN IRAN
}

\author{
Fereshteh MOLLA MOHAMMADI \\ Islamic Azad University, BuinZahra Branch, BuinZahra, Iran \\ Corresponding author's e-mail: Fe.mohammadi1985@gmail.com
}

\begin{abstract}
Foreign investment is a critical development strategy. The aim of the study was to investigate the factors affecting the attraction of foreign investment in Iran. The statistical population included foreign investment companies covered by the Foreign Investment Promotion and Protection Act and some experts from investment licensing executive agencies in Tehran province. A total of 400 subjects were enrolled in 2014-2017. The data analysis was performed using Kolmogorov-Smirnov test. All foreign investment companies covered by the investment promotion and protection law were studied by sampling. In addition, a non-random sampling method was used at the experts' level in the operating systems and executive organisations. In the present research, the Cochran formula was used to determine the sample size being 400 subjects. As a result, 550 questionnaires were distributed and completed; finally, 400 questionnaires were received and analysed in a correct and complete manner. Within the framework of the research, the parametric test (t-test) and linear regression were used for data analysis and the hypotheses due to normal distribution. After analysing the data collected from results of the respondents' responses and based on mathematical and statistical models, the most important factors affecting foreign investment attraction were the economic factor $(p<0.001)$ followed by the social factor $(p=0.002)$, the administrative bureaucracy $(p=0.003)$, cultural factor $(p=0.021)$ and the agent of the state $(p=0.031)$, all of which exhibited a significant relationship. Based on the results, the economic and cultural factors were the most effective parameters affecting foreign investment.
\end{abstract}

Keywords: bureaucracy, culture and society, economics, foreign investment.

\section{INTRODUCTION}

The attraction of foreign investment has become the most important concern of today's managers in today's societies (Asiedu, 2002). Economic experts believe that achieving rational growth and sustainable development are a key to solving economic problems, especially investment. On the other hand, investing is associated with many factors that affect the bulk of its flow and lead to its free flow. Earning profit is undoubtedly considered to be the main motive for the investor's incentive, and the investor does not invest without reliance on profitability without knowing the costs and facilities of returning it (Aharoni, 2015). For foreign investment, interests include transfer of capital, job creation, technology transfer, and access to the product market. In the past decade, the turbulent state of the international flow of capital and global economic developments have affected the 
phenomenon of recruitment in different countries, especially Iran, and raised problems in this regard (Sornarajah, 2017). The formation of private capital and its growth in any economy require the emergence of an appropriate space for investment. Therefore, institutionalization processes and policies should be set up to provide a good incentive structure for investment and widespread participation of the non-governmental sector in the country's economy (Kojima, 2010). The investment barriers include economic barriers and non-economic barriers. In addition, a lack of transparent government policies, instability in policies after state change, lack of relative stability in tariffs and prices, lack of transparency in production, lack of transparency in the provision of statistics and information (government agents) influence this situation (Harrison \& Rodríguez-Clare, 2010).

In the East, such as in Iran, although the term "investment" has a more or far ancient orientation compared to the West, a lack of its specific literature has led to a lack of appropriate investment despite cultural, social and economic background. On the other hand, the notion that the investor first of all comes to personal gain in his everyday life (which is still dominant) was a controversy that had originated from the class of unproductive and dispassionate brokers, whereas the distinction between these two parts in the West was well known (Blomstrom, 2014). The public culture is unaware of the distinction between the manufacturer and the non-expert dealer, and the custodians do not take action in this regard either. Regarding "changing investment behaviour in today's Iran", there are two main points of view: there is an argumentation that the domestic and foreign policy conditions have been arranged in such a way that the "investment" variable reacts negatively to this situation (private sector investment). The proponents of this view believe that the negative reaction of the investment variable is active in a number of ways (Brink, 2017). First, the desire for new investment has stabilized or decreased. Second, the development of previous investments is cautious and, third, the desire to invest abroad has increased. Issues such as the introduction of new regulations, curbing inflation, preventing the growth of the state, the monopolization of the state on the economy, especially intervention in investment projects, and so on, in the event of a lack of proper and misplaced decision-making and even disregard of the time situation, can violate citizens' property rights (Simma, 2011). One of the most important components of economic growth in any government with any political or economic procedure is the centralised or market-oriented system, the stability of the decision-making process, and the extreme avoidance of the test and error method. Unfortunately, one of the oldest and most damaging problems encountered in the years after the country's revolution was the plurality of decision-making centres, instability in the laws, and the making of false and one-night decisions. Investors, however, tend to ensure acceptable profitability of projects, the components of the investment climate, such as ensuring the absolute security margin based on the absence of invasion and political, governmental, legal and cultural misconduct on the investor or brought to them in non-existence systems, land, building, machinery, and know-how technical information (Du, Harrison, \& Jefferson, 2012). The youth of the country's population and the requirements for creating a job and productive labour for them, as well as globalization, the expansion of the market and international competition give Iran the potential of 
sustainable investment. Furthermore, the existence of rich resources, the geographic location of Iran, the presence of educated young people and the low value of the Iranian rial against the dollar are some of the relative advantages that have made Iran a supreme position for investment. The aim of the research was to identify barriers to attracting foreign investment in the investment companies in Iran.

\section{MATERIALS AND METHODS}

The statistical population of the research included foreign investment companies covered by the Foreign Investment Promotion and Protection Act and some experts from licensing executive organisations in Tehran province. A total of 400 respondents were investigated by random sampling during the period of 2014-2017. Since the aim of the research was to identify barriers to attracting foreign investment in the investment companies, the interview method was used to collect qualitative data in order to identify the main areas of the problems, and questionnaires of the research project were prepared. After the replies from the questionnaire were collected, it was necessary to properly arrange them. In the case of unanswered questions, they had to be examined in a specific way, and then the data had to be coded, categorized and tagged. Moreover, decisions about how to analyse data were made by computer. It was of the utmost importance to summarise and categorise the information accurately because it allowed extending and generalising it. The data were collected by preparing each questionnaire which scored from 1-5, including very low, low, moderate, high and very high. To answer the research questions, the following three methods were used to collect data.

1. Viewing the status of existing foreign investment companies in the province of Tehran regarding the subject of research.

2. Interviews with foreign experts and investors over the factors affecting investment barriers.

3. Using a questionnaire designed at the level of executives and investment experts of executive agencies.

In the research, the Kolmogorov-Smirnov test was used to evaluate the hypotheses due to the normal distribution. The SPSS software version 22 was used to analyse the data considering $95 \%$ confidence interval and $p<0.05$ as a significant result.

\section{RESULTS}

The results of the sample population indicated that $88 \%$ of males and $12 \%$ females participated in the survey. Furthermore, results of statistical descriptions of respondents' marital status indicated that married people $(80 \%)$ were predominant and single individuals comprised $20 \%$ of population. 
Table 1. The Kolmogorov-Smirnov Test for the Study of the Economic Factor, Bureaucracy, Governmental, Cultural and Social Factors in Tehran Investment Services Centre

\begin{tabular}{|l|l|r|r|r|r|r|}
\hline \multicolumn{2}{|l|}{ Description } & $\begin{array}{c}\text { Economic } \\
\text { factor }\end{array}$ & \multicolumn{1}{c|}{$\begin{array}{c}\text { Bureaucracy } \\
\text { factor }\end{array}$} & $\begin{array}{c}\text { Government } \\
\text { factor }\end{array}$ & $\begin{array}{c}\text { Cultural } \\
\text { factor }\end{array}$ & $\begin{array}{c}\text { Social } \\
\text { factor }\end{array}$ \\
\hline Sample size & 400 & 400 & 400 & 400 & 400 \\
\hline $\begin{array}{l}\text { Normal } \\
\text { parameters }\end{array}$ & Mean & 3.82 & 3.21 & 3.54 & 3.76 & 3.11 \\
\hline $\begin{array}{l}\text { Highest } \\
\text { difference }\end{array}$ & Standard & 0.716 & 0.442 & 0.698 & 0.432 & 0.341 \\
\cline { 2 - 8 } & Pure & 0.065 & 0.059 & 0.066 & 0.037 & 0.016 \\
\cline { 2 - 8 } & Positive & 0.065 & 0.044 & 0.066 & 0.037 & 0.016 \\
\cline { 2 - 8 } & Negative & -0.029 & -0.059 & -0.023 & 0.014 & -0.017 \\
\hline Kolmogorov-Smirnov & 0.632 & 0.568 & 0.638 & 0.874 & 0.0745 \\
\hline Significance level & 0.819 & 0.904 & 0.811 & 0.554 & 0.334 \\
\hline
\end{tabular}

As shown in Table 1, the significant level model was $>0.05$, thus at $95 \%$ level; zero assumption was rejected. Therefore, the data were normal and tests could be performed in parametric method.

According to the results of SPSS 22 in regression analysis, the observed (sig) level was less than $5 \%$. There was a significant relationship between the "economic factor" and "bureaucracy" and "state" and "cultural" and "social" factors. Pearson's correlation coefficient between "economic factor" and "attracting foreign investment" was equal to 0.873 ; that between "bureaucracy" and "attraction of foreign investment" was equal to 0.817 ; that between "government factor" and "attraction of foreign investment" was equal to 0.899 ; that between "cultural factor" and "foreign investment attraction" was equal to 0.645 and that between "social factor" and "foreign investment attraction" was equal to 0.439 . When correlation was established, the relationship between the research factors could be measured by regression test.

In addition, there was a significant relationship between the economic factor with foreign investment attraction and a unit of change in the economic factor variable caused 0.720 change per capita in foreign investment attraction $(p=0.011)$. Moreover, since the significant value was less than 0.05 , the variables could not be excluded from the regression equation. 
There was a significant relationship between the bureaucratic agent and foreign investment attraction $(p<0.05)$, thus the assumption of the linearity of the independent and dependent variables was acceptable. Furthermore, there was a significant relationship between the cultural factor and the attraction of foreign investment $(p<0.05)$.

There was a significant relationship between the state agent and foreign investment attraction. To evaluate the effect of independent variable on the dependent variable, the standardized coefficient column was used. Accordingly, a unit of change in the government factor created $146 \%$ change in competitive advantage. Furthermore, since the sig value was less than 0.05 , the variables could not be excluded from the regression equation. A significant relationship was observed between the social factor and foreign investment attraction $(p<0.05)$. To evaluate the effect of independent variable on the dependent variable, a standardized coefficient column was used. Accordingly, a unit of change in the intellectual capital variable generated $453 \%$ change in the social factor $(p<0.05)$.

Foreign investment requires the establishment of an appropriate situation for investment in any economy. Therefore, institutions, processes, and policies should be implemented to provide a suitable incentive structure for investments and the broad participation of the non-state sector in the country's economy (Anwar \& Sun, 2011).

In the study, a significant relationship was observed between the attraction of foreign investment and each of factors assessed and analysed, including economic factor, the administrative bureaucratic agent, governmental, cultural and social factors.

The results demonstrated that the economic factor was the most important factor in foreign investment attraction, followed by the social factor, the factor of administrative bureaucracy, cultural and governmental factors.

According to the research results, the existence of economic sanctions is the most important factor for reducing investment attraction in the field of economic issues. Sanctions have exploited the internal economic system's deficiencies and vulnerabilities and have disturbed the system. In fact, the economic system of Iran has suffered from deficiencies, which had been revealed with the sanctions. In this way, sanctions should be used to better identify the weaknesses and vulnerabilities of the national economy, and to take steps to reform the system more quickly and accurately. The strategies to be pursued to reform the economic system are as follows: reducing dependence on crude oil exports, creating economic transparency, paying attention to the benefits of the country in different sectors, and helping boost production in those sectors, paying attention to science and technology, and generating wealth from science, reforming tariff and tax regimes, applying policies to improve the pattern of consumption, in particular, in the water and energy sector, etc.

Government policies are also an important issue, which economic actors are considering when it comes to how the government is approaching investment attraction. The most important line of business can be to develop and enhance the competitiveness of economic activities, reduce monopoly and improve the business environment to expand production and investment activities, create competition, 
and encourage enterprises of the private sector to develop advanced technologydriven processes for developing export capacity and pay attention to the attraction of foreign investment (Sornarajah, 2017; Zamani-Farahani \& Henderson, 2010). The relative stability of tariffs and prices has been one of the demands of investors and their problems.

The growing role of statistics and information as a prerequisite for all decisionmaking, policy making and planning is not covered by anyone. This role in the information age is so evident that the statistical system of countries and the volume and quality of their information banks are not only one of the most important indicators of development of countries, but also mutually the policies and plans of economic, social and cultural development of countries without access. It is not possible to have adequate, accurate, and timely statistics (Jandhyala, Henisz, \& Mansfield, 2011; Salacuse, 2017). The importance of statistical information in all planning affairs, including policy making, goal setting, policies, executive direction, and finally the assessment of their success rate or failure, is high that many consider statistical information as the basis for planning and it is also considered that creating an efficient and effective system in production and supply of statistics is a prerequisite for planning and policy making. In addition to the many problems that exist in the country's planning system, which have led to a lack of success of the programmes in pursuit of economic development, problems of the statistical system and those problems arisen from it and the lack of transparency of statistics and detailed information are notable. Stability in policies after the change in management in the provinces and the lack of distinction between production and service sectors, the general principles and problems of the state should be also addressed (Riasi \& Amiri Aghdaie, 2013; Ruf \& Weichenrieder, 2012; Simma, 2011).

According to the results of the research, the most important work regarding the bureaucracy and administrative factor in the province is obtaining permissions from the executive agencies of the province. With reviews, licensing such as water, land use change, and the issuance of electricity and gas permits (energy) have been accompanied by a long workflow in specialized working groups of executive bodies and have created numerous problems for foreign investors. Paying attention to the customs administration is one of the main problems of foreign investors (Cairncross, 2015; Penrose, 2017).

Consequently, the lack of technology and technical knowledge is a critical factor in Tehran. Technology is an important factor for innovation and sustainable business evolution. In the new era, known as the information age, having technical knowledge of production would make a competitive advantage for investors (Blomstrom, 2014; Papadopoulos, Ibrahim, De Nisco, \& Napolitano, 2018; Seid, 2018). The value of technical knowledge is crucial based on research costs, innovation, creativity and management; therefore, maintaining the existing technical knowledge and trying to acquire new technical knowledge for the foreign investment sector will lead to survival in the market. The limitations of this study included: 1. Lack of access to information of major shareholders in foreign investment. 2. The absence of an investment unit window between foreign licensing entities. 3. Lack of access to correct and actual statistics based on the latest 
information on foreign investment. 4. Lack of precise identification of barriers of production and foreign investment.

\section{CONCLUSION}

In the study, a significant relationship was observed between the attraction of foreign investment and each of factors assessed and analysed, including economic factor, the administrative bureaucratic agent, governmental, cultural and social factors. After analysing the data collected from results of the respondents' responses and based on mathematical and statistical models, the most important factors affecting foreign investment attraction were the economic factor $(p<0.001)$ followed by the social factor $(p=0.002)$, the administrative bureaucracy $(p=0.003)$, cultural factor $(p=0.021)$ and the agent of the state $(p=0.031)$, all of which exhibited a significant relationship. From the results, the economic and cultural factors were the most effective parameters affecting foreign investment.

\section{ACKNOWLEDGEMENTS}

The study has been supported by Islamic Azad University, Booin Zahra Branch, Iran.

\section{REFERENCES}

Aharoni, Y. (1966). The foreign investment decision process. The International Executive, 8(4), 13- 14. https://doi.org/10.1002/tie.5060080407

Anwar, S., \& Sun, S. (2011). Financial development, foreign investment and economic growth in Malaysia. Journal of Asian Economics, 22(4), 335-342. https://doi.org/10.1016/j.asieco.2011.04.001

Asiedu, E. (2002). On the determinants of foreign direct investment to developing countries: is Africa different? World development, 30(1), 107-119. https://doi.org/10.1016/S0305$\underline{750 X(01) 00100-0}$

Blomstrom, M. (2014). Foreign Investment and Spillovers (Routledge Revivals). London: Routledge.

Brink, C. H. (2017). Measuring political risk: risks to foreign investment: Routledge.

Cairncross, A. K. (2015). Home and foreign investment, 1870-1913: Cambridge University Press.

Du, L., Harrison, A., \& Jefferson, G. H. (2012). Testing for horizontal and vertical foreign investment spillovers in China, 1998-2007. Journal of Asian Economics, 23(3), 234-243. https://doi.org/10.1016/j.asieco.2011.01.001

Harrison, A., \& Rodríguez-Clare, A. (2010). Trade, foreign investment, and industrial policy for developing countries. Handbook of development economics, 5, 4039-4214: Elsevier. https://doi.org/10.1016/B978-0-444-52944-2.00001-X

Jandhyala, S., Henisz, W. J., \& Mansfield, E. D. (2011). Three waves of BITs: The global diffusion of foreign investment policy. Journal of Conflict Resolution, 55(6), 1047-1073. https://doi.org/10.1177/0022002711414373

Kojima, K. (2010). Direct Foreign Investment: A Japanese Model of Multi-National Business Operations. London: Routledge. https://doi.org/10.4324/9780203845660

Papadopoulos, N., Ibrahim, Y., De Nisco, A., \& Napolitano, M. R. (2018). The Role of Country Branding in Attracting Foreign Investment: Country Characteristics and Country Image. Mercati e competitività, 2, 85-108. https://doi.org/10.3280/MC2018-002005

Penrose, E. T. (2017). Foreign Investment and the Growth of the Firm 1. International Business: Routledge, 33-48. 
Riasi, A., \& Amiri Aghdaie, S. (2013). Effects of a hypothetical Iranian accession to the world trade organization on Iran's flower industry. Consilience: The Journal of Sustainable Development, 10(1), 99-110.

Ruf, M., \& Weichenrieder, A. J. (2012). The taxation of passive foreign investment: lessons from German experience. Canadian Journal of Economics/Revue canadienne d'économique, 45(4), 1504-1528. https://doi.org/10.1111/j.1540-5982.2012.01737.x

Salacuse, J. W. (2017). BIT by BIT: The growth of bilateral investment treaties and their impact on foreign investment in developing countries. Globalization and International Investment: Routledge, 25-45.

Seid, S. H. (2018). Global regulation of foreign direct investment: Routledge.

Simma, B. (2011). Foreign Investment Arbitration: A Place for Human Rights? International \& Comparative Law Quarterly, 60(3), 573-596. https://doi.org/10.1017/S0020589311000224

Sornarajah, M. (2017). The international law on foreign investment: Cambridge university press. https://doi.org/10.1017/9781316459959

Zamani-Farahani, H., \& Henderson, J. C. (2010). Islamic tourism and managing tourism development in Islamic societies: the cases of Iran and Saudi Arabia. International journal of tourism research, 12(1), 79-89.

\section{AUTHOR'S SHORT BIBLIOGRAPHY}

Fereshteh Molla Mohammadi is Master of Business Administration from Islamic Azad University, BuinZahra Unit, Iran. He graduated in management in 2014 and received the Master's degree in 2017. The fields of his interest include management, business and economics. Currently he works at an insurance corporation in Tehran.

E-mail: Fe.mohammadi1985@gmail.com 